\title{
Investigation of the IL-1 $\beta$ Genotype and its Levels on Patients Treated with Osteointegrated Dental Implants
}

\author{
Osteointegre Dental İmplant Tedavisi Gören Hastalarda IL-1 $\beta$ Genotipi ve \\ Seviyelerinin İncelenmesi
}

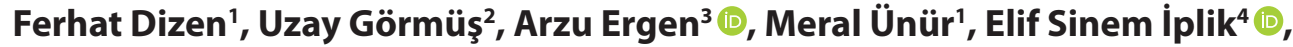 \\ Bedia Çakmakoğlư ${ }^{3}$, Turgay İsbir 5
}

'Department of Surgery, Istanbul University School of Dentistry, İstanbul, Turkey

2Department of Health Management, Nişantaşı University School of Economics, Administrative and Social Science, İstanbul, Turkey

${ }^{3}$ Department of Molecular Medicine, Aziz Sancar Institute of Experimental Medicine, İstanbul University, İstanbul, Turkey

${ }^{4}$ Department of Pharmaceutical Microbiology, İstanbul Yeni Yuzyil University School of Pharmacy, İstanbul, Turkey

${ }^{5}$ Department of Medical Biology, Yeditepe University School of Medicine, Istanbul, Turkey

Cite this article as: Dizen F, Görmüş U, Ergen A, Ünür M, Iplik ES, Çakmakoğlu B, et al. Investigation of the IL-1 $\beta$ Genotype and its Levels on Patients Treated with Osteointegrated Dental Implants. Experimed 2019; 9(1): 11-5.

\begin{abstract}
Objective: In our study, we aimed to investigate the relationship between the Interleukin-1 $\beta(\mathrm{IL}-1 \beta)+3953$ gene polymorphism, the levels of this interleukin and smoking in osteointegrated dental implant losses.
\end{abstract}

Materials and Methods: 56 patients with implants and 238 healthy control subjects were included in this study. PCR and RFLP methods was used to determine the IL- $1 \beta+3953$ gene polymorphisms. Serum IL- $1 \beta$ levels were measured using ELISA.

Results: The IL-1 $\beta+3953$ CC, TT and CT genotype frequencies for the controls and study cases were $61.2 \%, 10.1 \%, 43.6 \%$, and $48.2 \%, 8.9 \%$ and $42.9 \%$, respectively. IL- $1 \beta+3953$ T allele carriers increased more in the patient group (51.8\%) compared to the control group (38.8\%). These cases also had an increased plaque index, bleeding index, pocket deepness and serum IL-1 $\beta$ levels, but none of them were statistically significant $(p>0.05)$. Implant losses were more frequent in $\mathrm{C}$ allele carriers than in T allele carriers, but this was not statistically significant $(p>0.05)$ Three of the five patients that experienced implant loss and smoked, lost the implant earlier and had a higher average plaque and bleeding index.

Conclusion: Based on our results, we can suggest that being an IL$1 \beta$ positive genotype and a smoker can have an effect on implant losses. The study group should be enlarged to comment with statistically significant results.

Keywords: IL-1 $\beta+3953$, Implant, Interleukin, polymorphism öz

Amaç: Çalışmamızda osteointegre dental implant kayıplarında interlökin-1 $\beta$ (IL-1 $\beta)+3953$ gen polimorfizminin serum interlökin düzeyleri ve sigara içimiyle ilişkisini araştırmayı amaçladık.

Yöntemler: Implant yapılan 56 olgu ve 238 sağlıklı kontrol öalışmaya dahil edilmiştir. IL-1 $\beta+3953$ polimorfizmi, polimeraz zincirleme reaksiyonu ve restriksiyon fragmanı uzunluk polimorfizmi yöntemleri kullanılarak tayin edilmiştir. Serum örneklerinde IL-1 $\beta$ seviyesi ELISA yöntemi ile saptanmıştır.

Bulgular: IL-1 $\beta+3953$ polimorfizmi; CC, TT ve CT genotip frekansları kontrol ve hasta grubu için sırasıyla $61.2 \%, 10.1 \%, 43.6 \%$, ve $48.2 \%, 8.9 \%$ ve $42.9 \%$ olarak bulunmuştur. IL- $1 \beta+3953$ T alleli taşıyanların hastalarda (51.8\%) kontrol grubuna (38.8\%) göre daha yüksek bulunmuştur ve bu kişilerde plak indeksi, kanama indeksi, cep derinliği ve serum IL-1 $\beta$ düzeylerinin arttığı, sigara içme ve implant kaybı oranının yükseldiği fakat istatistiksel anlamlılığa ulaşmadığı tespit edilmiştir ( $p>0,05)$. İmplant kaybında, $C$ alleli taşıyanlarda $\mathrm{T}$ alleli taşıyanlara göre daha anlamlı bulunmasına rağmen istatistiksel olarak anlamlı olmadığı görülmüştür $(p>0,05)$. Implant kaybı olan beş hastanın üçünde IL-1 $\beta$ pozitif olduğu, hepsinin sigara kullandığı, implantların erken dönemde kaybedildiği, plak ve kanama indekslerinin ortalama değerlerden yüksek olduğu ve cep derinliklerinin normal sınırlar arasında olduğu görülmüştür.

Sonuç: Sonuç olarak implant kaybında IL-1 $\beta$ pozitif genotipe sahip olma ve sigara içiminin önemli bir etken olduğu izlenimi edinilmiş ancak olgu sayısının arttırımasıyla istatistiksel anlamlılığa ulaşılabileceği sonucuna ulaşılmıştır.

Anahtar Kelimeler: IL-1 $\beta+3953$, implant, interlökin, polimorfizm 


\section{INTRODUCTION}

Examples of biological complications in dental implants can be summarized as; fistula formation, inflammatory reactions around the implant sulcus, periimplant mucositis and periimplantitis (1). Dental implant success rates range between $95 \%$ and $99 \%$, but there can be implant losses later due to biological and technical complications (2-5). It was found that there were two main reasons for implant losses $(6,7)$ : 1 . The biofilm layer over the implant surface might cause enflamatory reactions and bone losses occur; 2 . Biomechanical burden and genetic factors.

Interleukin 1 (IL-1), prostoglandin E2 (Pg E2) and matrix metalloproteinases (MMP) are usually connected with both the seriousness and activity of the periodontal disease (8). Previously, people carrying at least one $\mathrm{T}$ allele have been described as IL-1 genotype-positive (8-10). Thus, we used this term in our study as suggested. It has previously been demonstrated that there is a 2.7 times higher risk of dental losses in IL-1 genotype positive patients compared to IL-1genotype negative ones (11). In a retrospective study it was shown that $I L-1$ positive genotype patients had a significantly higher risk of bleeding (12).

There are two main theories for the bone-implant relationship. One is the initially accepted theory of fibro-osseos integration - it is known that there is an organised collagen mesh between the bone and implant surfaces. This fibro-osseos sttructure is just like periodontal membrane, but it was thought that as they were arranged parallel to the implant surface, they were weakening the bone-implant relationship (13). The second theory is known as the 'osteo-integration' theory, and was first defined by Branemark et al. (14) as a direct relationship between the bone tissue and the implant (14).

Interleukin-1 (IL-1) is a type of cytokine that is secreted from macrophages/monocytes and mainly activates $T$ helper cells. Recently, more preimplant infections were detected in patients with increments of IL- 1 compared to healthy patients and it was demonstrated that in those people with periodontal infections and increased cytokines, there were 2.7 times more dental losses than in other patients (15). It was found that proinflamatory cytokine $I L-1 \beta$ was significantly higher in the perimplantitis area than in healthy areas $(16,17)$. IL- 1 is now thought to be major mediator in chronic inflamatory cases such as periodontitis (18). In the scope of all of those studies it was also realised that specific gene polymorphisms of the IL-1 gene region might be related to periodontitis risk $(19,20)$.

The aim of our study was to investigate the relationship between the $I L-1 \beta 3953$ polymorphism and complications in osteointegrated dental implants, to determine the differential complications between smoking and non-smoking patients and to identify the success of dental implants in relation to periodontal diseases.

\section{MATERIALS AND METHODS}

\section{Study Subjects}

Our study was approved by the İstanbul University Medical Ethics Committee (03/10/2006 and 041895). All subjects provided written informed consent before they participated in the study. All participants signed an informed consent before enrollment and Institutional Ethical committee approval was obtained for the study. The patient group (26 males and $30 \mathrm{fe}-$ males) was chosen from those attending the Faculty of Dentistry, in the Department of Oral Medicine and Oral Surgery. The control group contained 238 healthy participants ( 88 males and 150 females). The inclusion criteria for the patient group of the study were: optimal oral hygiene alongside no history of partial or total loss of teeth, bruxism, previous chemotherapy or radiotherapy, alcohol or drug addiction.

All surgical procedures were carried out under local anesthesia. The implants were engrafted using the standard protocol Zimmer Dental Tapered Screw-Vent / Swiss Plus dental implant system. In total, 126 implants were used over 56 patients. EDTA-tubes were used for DNA analysis. Before the operation and on 8th week following the operation, serum specimens were taken and maintained at $-20{ }^{\circ} \mathrm{C}$ to determine $I L-1 \beta$ levels. All measurements and determinations were performed in the Department of Molecular Medicine, Istanbul University.

\section{Polymorphism Analysis and ELISA}

The method previously described by Sun et al. (21) was used. The primers used for the polymerase chain reaction (PCR) for the $I L-1 \beta+3953$ localization were: forward 5'-GTT GTC ATC AGA CTT TGA CC-3', and reverse, 5'-TTC AGT TCA TAT GGA CCA GA-3' from (MBI Fermentas, Vilnius, Lithuania). The gene fragments were amplified using a $25 \mu \mathrm{L}$ reaction mixture containing approximately $100 \mathrm{ng}$ of template DNA, $0.5 \mu \mathrm{L}$ of each primer, all four deoxyribonucleoside $5^{\prime}$ triphosphates (each at $0.2 \mathrm{mM}$ ), $1.5 \mathrm{mM} \mathrm{MgCl} 2$ and $1.0 \mathrm{U}$ of Taq polymerase in a $1 \mathrm{x}$ reaction buffer (MBI Fermentas, Vilnius, Lithuania). The PCR reaction was carried out with an initial melting stage of 5 minutes at $94^{\circ} \mathrm{C}$; followed by 35 cycles of 1 minute at $94^{\circ} \mathrm{C}, 1$ minute at $55^{\circ} \mathrm{C}, 1$ minute at $72^{\circ} \mathrm{C}$, and a final elongation step of 7 minutes at $72^{\circ} \mathrm{C}$.

The restriction endonuclease Taq I was used to determine the $I L-1 \beta+3953$ polymorphism. The Taq I digestion generated fragments of $135 \mathrm{bp}$ and $114 \mathrm{bp}$ for the $\mathrm{C}$ allele, and for the T allele, a single fragment of $249 \mathrm{bp}$. PCR and restriction products were electrophoresed in in $2 \%(\mathrm{w} / \mathrm{v})$ agarose gels and stained with ethidium bromide (Figure 1).

Determination of Serum IL-1 $\beta$ Levels was performed using commercial ELISA (Enzyme Linked Immunosorbent Assay) assay kits (Biosource, Nivelles, Belgium).

\section{Statistical Analysis}

The student's t test and Anova were used to determine the effects of genotypes and alleles on the activities. The Serum $I L-1 \beta$ levels of the patient and control groups were compared using the Wilcoxon test. Pearson analyses were used to examine the 


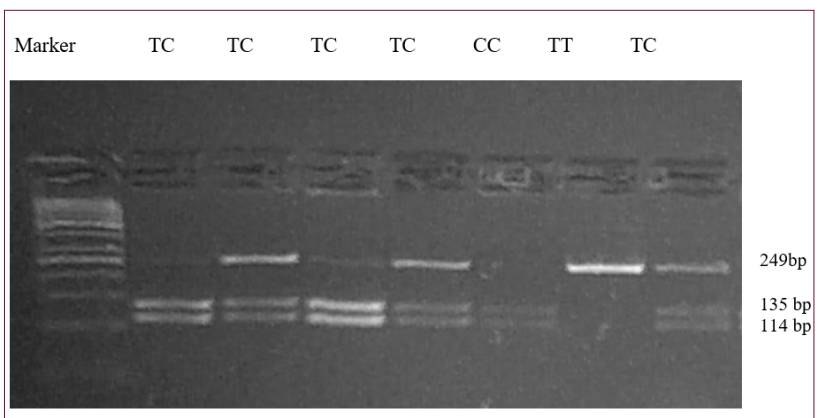

Figure 1. Gel electrophoresis after restriction of the IL-1 $\beta+3953$ gene region

Taq I digestion generated the following fragments for the $\mathrm{C}$ allele, fragments of $135 \mathrm{bp}$ and $114 \mathrm{bp}$; T allele, a single fragment of $249 \mathrm{bp}$ and were electrophoresed in in $2 \%(\mathrm{w} / \mathrm{v})$ agarose gels and stained with ethidium bromide

Table 1. The study parameters in patient and control groups

\begin{tabular}{|c|c|c|}
\hline & Control $(n=238)$ & Patient $(n=56)$ \\
\hline (Female/Male) & $150 / 88$ & $30 / 26$ \\
\hline Age (years) & $43.70+15.06$ & $46.46+12.00$ \\
\hline Plaque index & & $40.82 \pm 17.39$ \\
\hline Bleeding index & & $32.68 \pm 18.69$ \\
\hline Pocket Deepness (mm) & & $1.81 \pm 0.45$ \\
\hline IL-1 $\beta$ I level $(\mathrm{pg} / \mathrm{mL})^{*}$ & $0.415 \pm 0.71$ & $0.780 \pm 0.9340$ \\
\hline IL-1 $\beta$ || level $(\mathrm{pg} / \mathrm{mL})^{* *}$ & & $0.837 \pm 1.4483$ \\
\hline $\begin{array}{l}\text { All values of the table were giv } \\
{ }^{*} \text { IL-1 } \beta \text { I level: IL-1 } \beta \text { levels imme } \\
\text { **IL-1 } \beta \text { II level: IL-1 } \beta \text { levels } 8 \text { we }\end{array}$ & $\begin{array}{l}\text { as mean } \pm \text { standart dev } \\
\text { iately before the operat } \\
\mathrm{ks} \text { after the operation }\end{array}$ & $\begin{array}{l}\text { ation }(x \pm S D) \\
\text { on }\end{array}$ \\
\hline
\end{tabular}

Table 2. IL-1 $\beta+3953$ genotype and allele frequencies in groups

\begin{tabular}{lccc}
\hline \multicolumn{1}{c}{ Control } & Patient & p \\
\hline IL-1 $\beta+3953$ Genotype & & & \\
\hline CC & $145(61.2 \%)$ & $27(48.2 \%)$ & \\
\hline TT & $24(10.1 \%)$ & $5(8.9 \%)$ & \\
\hline TC & $68(43.6 \%)$ & $24(42.9 \%)$ & 0.11 \\
\hline C+ & $213(89.9 \%)$ & $51(91.1 \%)$ & 0.78 \\
\hline T+ & $92(38.8 \%)$ & $29(51.8 \%)$ & 0.07 \\
\hline
\end{tabular}

differences in genotype distribution between the patients and the control subjects. The Chi-Square, Fisher Kruskal Wallis and Mann-Whitney tests were used to differentiate the genotype and allele frequencies between the groups.
Table 3. The results of IL-1 $\beta$ positive and negative patients

\begin{tabular}{|c|c|c|}
\hline & IL-1 $\beta(-)$ (n:27) & IL-1 $\beta(+)$ (n:29) \\
\hline $\begin{array}{l}\text { Gender } \\
\text { (Female/Male) }\end{array}$ & $14 / 13$ & $16 / 13$ \\
\hline $\begin{array}{l}\text { Smoking(\%)/ } \\
\text { non-smoking(\%) }\end{array}$ & $12(37.5) / 15(62.5)$ & $20(62.5) / 9(37.5)$ \\
\hline $\begin{array}{l}\text { Implant loss(\%)/ } \\
\text { No implant loss (\%) }\end{array}$ & $2(40.0) / 25(49.0)$ & $3(60.0) / 26(51.0)$ \\
\hline Age (year) & $44.11 \pm 13.80$ & $48.66 \pm 9.78$ \\
\hline Plaque Index & $39.58 \pm 15.67$ & $41.98 \pm 19.06$ \\
\hline Bleeding Index & $30.00 \pm 15.42$ & $35.17 \pm 21.27$ \\
\hline $\begin{array}{l}\text { Pocket Deepness } \\
(\mathrm{mm})\end{array}$ & $1.73 \pm 0.37$ & $1.89 \pm 0.51$ \\
\hline IL1 level (pg/mL) & $0.65 \pm 0.72$ & $0.77 \pm 1.06$ \\
\hline
\end{tabular}

Values of the table were given as mean \pm standart deviation $(x \pm S D)$

\section{RESULTS}

There was no significant difference in the ages or interleukin levels between the groups ( $p>0.05$ ) (Table 1). There was no significant difference between the groups in terms of genotype or allele distribution ( $\mathrm{p}: 0.119 \times 2: 4.25$ ). The IL-1 $\beta+3953$ T allele carriers increased almost significantly in the patient group compared to the control group (p:0.076; X2:3.14; Odds ratio (OR) : $1.69 \% 95 \mathrm{Cl}: 0.94-3.04)$. (Table 2).

The IL-1 $\beta$ Positive cases had an increased plaque index, bleeding index, pocket deepness and serum $I L-1 \beta$ levels, but none of these values were statistically significant ( $p>0.05$ ) (Table 3 ).

Implant losses were more frequent in C allele carriers than in $\mathrm{T}$ allele carriers, but this was not statistically significant $(p>0.05)$ (Table 4).

It was also found that plaque index, bleeding index and pocket deepness increased in the case of implant loss, but this was also not significant $(p>0.05)$.

The IL-1 levels were not significantly different in the patient or control groups (p:0.858) (Table 5).

In the patient group it was determined that the IL-1 levels ( $p: 0.037)$ and plaque indices ( $p: 0.028)$ were significantly higher in females than in males (Table 6).

\section{DISCUSSION}

Pietruski et al. (22) found that IL-1 levels significantly increased one day after operation, but concluded that this was due to tissue damage as a result of implantation. We chose to take serum specimens on the same day of the operation and then 8 weeks after the operation to compare the IL-1 levels to eleminate the 
Table 4. Implant lossed due to IL-1 $\beta+3953$ genotypes

\begin{tabular}{lcc}
\hline & $\begin{array}{c}\text { No Implant Loss } \\
(\mathbf{n}=5 \mathbf{5})\end{array}$ & $\begin{array}{c}\text { Implant Loss } \\
(\mathbf{n}=5)\end{array}$ \\
\hline IL-1 $\beta$ GENOTYPE & & \\
\hline CC & $25(49 \%)$ & $2(40 \%)$ \\
\hline TT & $4(7.8 \%)$ & $1(20 \%)$ \\
\hline TC & $22(43.1 \%)$ & $2(40 \%)$ \\
\hline ALLELE & & $4(80 \%)$ \\
\hline C+ & $47(92.2 \%)$ & $1(20 \%)$ \\
\hline C- & $4(7.8 \%)$ & $3(60 \%)$ \\
\hline T+ & $26(51.0 \%)$ & $2(40 \%)$ \\
\hline T- & $25(49.0 \%)$ & \\
\hline
\end{tabular}

Table 5. IL-1 Levels in different genotypes and alleles of control and patient groups

\begin{tabular}{lcc}
\hline & \multicolumn{2}{c}{ IL-1 levels $(\mathbf{p g} / \mathbf{m L})$} \\
\cline { 2 - 3 } IL genotypes & Control Group & Patient Group \\
\hline CC & $0.43 \pm 0.73$ & $0.65 \pm 0.72$ \\
\hline TT & $0.51 \pm 1.12$ & $0.780 \pm 0.82$ \\
\hline TC & $0.32 \pm 0.44$ & $0.775 \pm 1.12$ \\
\hline C+ & $0.51 \pm 1.12$ & $0.714 \pm 0.92$ \\
\hline C- & $0.37 \pm 0.57$ & $0.780 \pm .82$ \\
\hline T+ & $0.39 \pm 0.73$ & $0.77 \pm 1.06$ \\
\hline T- & $0.438 \pm 0.73$ & $0.65 \pm 0.72$ \\
\hline All values of the table were given as mean \pm standart deviation $(x \pm S D)$ \\
\hline
\end{tabular}

Table 6. Gender differences of parameters in patient group

\begin{tabular}{lll}
\hline & Female (n:30) & Male (n:26) \\
\hline IL1 $\beta$ level $(\mathrm{pg} / \mathrm{mL})$ & $0.97 \pm 1.09$ & $0.45 \pm 0.55$ \\
\hline IL1 $\beta$ II level $(\mathrm{pg} / \mathrm{mL})$ & $0.68 \pm 1.19$ & $1.00 \pm 1.70$ \\
\hline Plaque Index & $45.43 \pm 21.58$ & $35.48 \pm 8.31$ \\
\hline Bleedig Index & $3.76 \pm 22.33$ & $30.28 \pm 13.36$ \\
\hline Pocket Deepness $(\mathrm{mm})$ & $1.88 \pm 0.51$ & $1.74 \pm 0.37$
\end{tabular}

All values of the table were given as mean+standart deviation $(x \pm S D)$

*IL-1 $\beta$ I level: IL-1 $\beta$ levels immediately before the operation

**IL-1 $\beta$ II level: IL-1 $\beta$ levels 8 weeks after the operation

post operation inflammation process, but we could not find any statistical difference between those results.
There was an incremental change in frequency of implant losses in C allele carriers, but not a statistically significant one ( $p>0.05$ ). The CT genotype was more frequent in the control group (albeit non-significantly) and this result correlates with the results of Sakellari et al. (23).

Rogers et al. (24) determined no relationship between IL-1 genotypes and implant loss. In another study, it was found that IL-1 gene polymorphism increased the periimplant infection frequency (25). In our study, we were able to conclude that bleeding index, plaque index and pocket deepness increased and as a result of all those parameter changes, the risk of periodontitis and periimplant also increased.

In a previous study, it was found that the risk of dental loss was 2.7 times higher in $I L-1$ positive cases than in $I L-1$ negative cases (26). In one study, it was previously found that periodontal diseases were more frequent in $I L-1$ positive people, and in the same study it was also demonstrated that the coincidence of IL-1 positivity and smoking significantly increased the risk of implant loss (27-29). We also found that 11 of the 24 smoking patients were successfully cured by the implants even though they were IL- 1 positive; 3 of the 5 patients with implant losses were $I L-1$ positive, but this was not a significant enough number to assess the relationship of IL-1 positivity and smoking in total.

When we compared the bleeding index, plaque index and pocket deepness of the patients with $(n=5)$ and without $(n=51)$ implant losses, all of those parameters increased in the former group, but the number of implant losses was not enough for statistical significance. When we compared the gender differences of the parameters in the patient group,the $I L-1$ levels 8 weeks after the operation ( $p: 0.037$ ) and plaque indices ( $p: 0.028$ ) were found to be significantly different.

Finally, supported by the previous studies, IL-1 positive patients were found to have an increased incidence of perimplantitis and periodontitis; a risk assesment can be carried out before implant surgery to have more successful results.

Ethics Committee Approval: Ethics committee approval was received for this study from the Medical Ethics Committee of Istanbul University (Decision Date: 03/10/2006; Decision Number: 041895).

Informed Consent: Written informed consent was obtained from the subjects who participated in this study.

Peer-review: Externally peer-reviewed.

Author Contributions: Concept - F.D., U.G., A.E., M.Ü., E.S.I., B.Ç., T.I.;; Supervision - F.D., U.G., A.E., M.Ü., E.S.I., B.Ç., T.I..; Data Collection and/ or Processing - F.D., U.G., A.E., M.Ü., E.S.I.., B.Ç., T.I.; Analysis and/or Interpretation - F.D., U.G., A.E., M.Ü., E.S.I., B.Ç., T.I.; Literature Search - F.D., U.G., A.E., M.Ü., E.S.I.., B.Ç., T.i.j; Writing - F.D., U.G., A.E., M.Ü., E.S.İ., B.Ç., T.I..; Critical Reviews - F.D., U.G., A.E., M.Ü., E.S.I., B.Ç., T.I.

Conflict of Interest: The authors have no conflict of interest to declare. 
Financial Disclosure: This work was supported by the Research Fund of the İstanbul University (Project number: T-2/15122006).

Etik Komite Onayı: Bu çalışma için etik komite onayı İstanbul Üniversitesi Etik Kurulu'ndan alınmıştır (Karar tarihi: 03/10/2006; Karar numarası: 041895).

Hasta Onamı: Çalışmaya katılanlardan yazılı hasta onamı alınmıştır.

Hakem Değerlendirmesi: Dış bağımsız.

Yazar Katkıları: Fikir - F.D., U.G., A.E., M.Ü., E.S.I., B.Ç., T.I.;; Denetleme - F.D., U.G., A.E., M.Ü., E.S.I., B.Ç., T.i..; Veri Toplanması ve/veya İşlemesi F.D., U.G., A.E., M.Ü., E.S.I., B.Ç., T.i.;; Analiz ve/veya Yorum - F.D., U.G., A.E., M.Ü., E.S.I., B.Ç., T.I.; Literatür Taraması - F.D., U.G., A.E., M.Ü., E.S.I., B.Ç., T.I..; Yazan - F.D., U.G., A.E., M.Ü., E.S.I., B.Ç., T.I.; Eleştirel İnceleme - F.D., U.G., A.E., M.Ü., E.S.I., B.Ç., T.I.

Çıkar Çatışması: Yazarlar çıkar çatışması bildirmemişlerdir.

Finansal Destek: Bu çalışma, İstanbul Üniversitesi Bilimsel Araştırma Projeleri Birimi tarafından desteklenmiştir (Proje No: T-2/15122006).

\section{REFERENCES}

1. Mombelli A, Van Oosten MA, Schurch E, et al. The microbiota associated with successful or failing osseointegrated titanium implants. Oral Microbiol Immunol 1987; 2: 145-51. [CrossRef]

2. Behneke A, Behneke N, d'Hoedt B. A 5-year longitudinal study of the clinical effectiveness of ITI solid-screw implants in the treatment of mandibular edentulism. Int J Oral Maxillofac Implants 2002; 7: 799-810.

3. Ferrigno N, Laureti M, Fanali S, et al. A long-term follow-up study of non-submerged ITI implants in the treatment of totally edentulous jaws. Part I: Ten-year life table analysis of a prospective multicenter study with 1286 implants. Clin Oral Implants Res 2002; 13: 260-73. [CrossRef]

4. Lemmerman KJ, Lemmerman NE. Osseointegrated dental implants in private practice: a long-term case series study. J Periodontol 2005; 76: 310-9. [CrossRef]

5. Brägger $U$. Use of radiographs in evaluating success, stability and failure in implant dentistry. Periodontol 2000 1998; 17: 77-88. [CrossRef]

6. Lindhe J, Berglundh T, Ericsson I, et al. Experimental breakdown of peri-implant and periodontal tissues. A study in the beagle dog. Clin Oral Implants Res 1992; 3: 9-16. [CrossRef]

7. Esposito M, Hirsch JM, Lekholm U, et al. Biological factors contributing to failures of osseointegrated oral implants. (II). Etiopathogenesis. Eur J Oral Sci 1998; 106: 721-64. [CrossRef]

8. Santamaria P, Gehrz RC, Bryan MK, et al. Involvement of class II MHC molecules in the LPS-induction of IL-1/TNF secretions by human monocytes. Quantitative differences at the polymorphic level. J Immunol 1989; 143: 913-22.

9. De Boever AL, De Boever JA. Early colonization of non-submerged dental implants in patients with a history of advanced aggressive periodontitis. Clin Oral Implants Res 2006; 17: 8-17. [CrossRef]

10. Greenstein G, Hart TC. Clinical utility of a genetic susceptibility test for severe chronic periodontitis: a critical evaluation. J Am Dent Assoc 2002; 133: 452-9. [CrossRef]

11. McGuire MK, Nunn ME. Prognosis versus actual outcome. IV. The effectiveness of clinical parameters and IL-1 genotype in accurate- ly predicting prognoses and tooth survival. J Periodont 1997; 70 : 49-56. [CrossRef]

12. Pociot F, Molvig J, Wogensen L, et al. A Taql polymorphism in the human interleukin-1b (IL-1b) gene correlates with IL-1b secretion in vitro. Eur J Clin Invest 1992; 22: 396-402. [CrossRef]

13. Spiekermann H, Jansen VK, Richter EJ. A 10-year follow-up study of IMZ and TPS implants in the edentulous mandible using bar-retained overdentures. Int J Oral Maxillofac Implants 1995; 10: 23143.

14. Branemark Pl, Adell R, Albrektsson T, et al. Osseointegrated titanium fixtures in the treatment of edentulousness. Biomaterials 1983; 4: 25-8. [CrossRef]

15. Laine $M L$, Leonhardt $A$, Roos-Jansaker $A-M$, et al. IL-1RN gene polymorphism is associated with peri-implantitis. Clin. Oral Impl Res 2006; 17: 380-5. [CrossRef]

16. Kao RT, Curtis DA, Richards DW, et al. Increased interleukin-1 beta in the crevicular fluid of diseased implants. Int J Oral Maxillofac Implants 1995; 10: 696-701.

17. Panagakos FS, Aboyoussef $H$, Dondero $R$, et al. Detection and measurement of inflammatory cytokines in implant crevicular fluid: a pilot study. Int J Oral Maxillofac Implants 1996; 11: 794-9.

18. Dinarello CA. The biological properties of interleukin-1. Eur Cytokine Network 1994;5:517-531.

19. Gemmell E, Marshall RI and Seymour GJ: Cytokines and prostaglandins in immune homeostasis and tissue destruction in periodontal disease. Periodontology 2000 1997; 14: 112-43. [CrossRef]

20. Kornman KS, Crane A, Wang HY, et al. The interleukin-1 genotype as a severity factor in adult periodontal disease. J Clin Periodontol 1997; 24: 72-7. [CrossRef]

21. Edwards RK, Ferguson RJ, Duff P. The Interleukin-1b +3953 Single Nucleotide Polymorphism: Cervical Protein Concentration and Preterm Delivery Risk American. J Reprod Immunol 2006; 55: 25964. [CrossRef]

22. Pietruski JK, Pietruska MD, Stokowska W, et al. Serum levels of interleukin-1 (IL-1), interleukin-6 (IL-6) and interleukin-8 (IL-8) in patients treated with dental implants. Rocz Akad Med Bialymst 2001; 46: 28-37.

23. Sakellari D, Koukoudetsos $S$, Arsenakis $M$, et al. Prevalence of IL-1A and IL-1B polymorphisms in a Greek population. J Clin Periodontol 2003; 30: 35-41. [CrossRef]

24. Rogers MA, Figliomeni L, Baluchova K, et al. Do interleukin-1 polymorphisms predict the development of periodontitis or the success of dental implants? J Periodontal Res 2002; 37: 37-41. [CrossRef]

25. Feloutzis A, Lang NP, Tonetti MS, et al. IL-1 gene polymorphism and smoking as risk factors for peri-implant bone loss in a well-maintained population. Clin Oral Implants Res 2003; 14: 10-17. [CrossRef]

26. McGuire MK, Nunn ME. Prognosis versus actual outcome. IV. The effectiveness of clinical parameters and IL-1 genotype in accurately predicting prognoses and tooth survival. J Periodontol 1999; 70 : 49-56. [CrossRef]

27. Kornman KS: Interleukin 1 genetics, inflammatory mechanisms, and nutrigenetic opportunities to modulate diseases of aging. Am J Clin Nutr 2006; 83: 475S-83S. [CrossRef]

28. Tonetti MS. Risk factors for osseodisintegration. Periodontol 2000 1998; 17: 55-62. [CrossRef]

29. Lindquist LW, Carlsson GE, Jemt T. Association between marginal bone loss around osseointegrated mandibular implants and smoking habits: a 10-year follow-up study. J Dent Res 1997; 76: 1667-74. [CrossRef] 